\title{
ESTIMATION OF WATER REQUIREMENTS AND VALUE OF WATER IN AGRICULTURAL SECTOR IN EAST JAVA: THE CASE OF RICE PLANT
}

\author{
Aditya Widya Permana ${ }^{1}$ \\ Deni Kusumawardani*2 \\ 1,2 Department of Economic, Faculty of Economics and Business, Universitas Airlangga, Indonesia
}

\begin{abstract}
Water resources is one of the inputs in rice production. In agricultural sector, water is considered as free good or priceless despite having a high use value. That implicated to the inefficient use of water in each provinces of Indonesia including East Java with no exception. This study aims to estimate the value of water and water requirements in agriculture especially rice in East Java. This study uses two quantitative analysis methods. The first method is the Penman-Montieth to calculate the water footprint and water requirements for rice. The second is benefit transfer method to estimate the value of water in rice production. Investigated areas are cities and municipals in East Java, while the study period is 2008 to 2011.The results showed that: (1) the average of water footprint in East Java from 2008 to 2011 was $3.556 \mathrm{~m}^{3} /$ ton. This value is affected by climate change, fertilizers, and yields. (2) The average of water requirements for rice in East Java from 2008 to 2011 was 35.913.244.065 $\mathrm{m}^{3}$. This value is greater than the value of water allocation is determined by the government. (3) The estimated value of water for rice production in East Java was Rp 4.500.060 per hectare for one growing season.
\end{abstract}

Keywords: Water Footprint, Water Requirements, Value of Water, Agriculture

JEL: Q1, Q25

\section{ABSTRAK}

Sumber daya air merupakan salah satu input dalam proses produksi tanaman padi. Di dalam sektor pertanian Indonesia, air dianggap tidak memiliki harga meskipun memiliki nilai guna yang tinggi. Hal tersebut mengakibatkan penggunaan air yang tidak efisien di tiap provinsi tak terkecuali Jawa Timur. Penelitian ini bertujuan untuk mengestimasi kebutuhan dan nilai air pada sektor pertanian subsektor tanaman pangan khususnya padi di Provinsi Jawa Timur. Penelitian ini menggunakan analisis kuantitatif dengan metode Penman-Montieth untuk menghitung water footprint dan kebutuhan air irigasi untuk tanaman padi serta metode benefit transfer untuk mengestimasi nilai air yang dibutuhkan untuk produksi tanaman padi. Daerah yang diteliti ialah kabupaten dan kota di Jawa Timur, sedangkan periode penelitian adalah tahun 2008 hingga 2011. Hasil penelitian ini menunjukkan bahwa: (1) rata-rata water footprint Jawa Timur dari tahun 2008 hingga 2011 sebesar $3.556 \mathrm{~m}^{3} /$ ton. Nilai tersebut dipengaruhi oleh perubahan iklim, penggunaan pupuk, dan produktivitas lahan. (2) Volume kebutuhan air untuk tanaman padi di Jawa Timur secara rata-rata dari tahun 2008 hingga 2011 sebesar 35.913.244.065 m³. Volume tersebut lebih besar dibandingkan dengan volume alokasi air yang ditentukan oleh pemerintah. (3) Estimasi nilai air untuk tanaman padi di Jawa Timur sebesar Rp 4.500.060 per hektar untuk satu kali musim tanam.

Kata Kunci: Water Footprint, Kebutuhan Air, Nilai Air, Pertanian

JEL: Q1, Q25

\section{RIWAYAT ARTIKEL}

Tanggal Masuk:

5 Juni 2021

Tanggal Revisi:

28 September 2021

Tanggal Diterima:

26 November 2021

Tersedia Online:

29 November 2021

*Korespondensi:

Deni Kusumawardani

E-mail:

deniku@feb.unair.ac.id

JIET (Jurnal IImu Ekonomi Terapan) p-ISSN: 2541-1470; e-ISSN: 2528-1879 


\section{Pendahuluan}

Pertanian merupakan salah satu sektor penting dalam perekonomian Indonesia. Menurut BPS (2012), sektor pertanian memilliki kontribusi yang cukup besar dalam produk domestik bruto (PDB) Indonesia, yaitu sebagai penyumbang terbesar ketiga setelah sektor industri pengolahan dan sektor perdagangan, hotel, dan restoran. Sektor pertanian juga merupakan penyumbang tenaga kerja terbesar di Indonesia, di mana terdapat 38\% tenaga kerja yang bekerja di sektor pertanian pada tahun 2010.

Sektor pertanian memiliki lima subsektor, yaitu subsektor tanaman bahan makanan, tanaman perkebunan, peternakan, kehutanan, dan perikanan. Menurut BPS (2011a), subsektor tanaman bahan makanan memiliki kontribusi tertinggi terhadap PDB Indonesia dibandingkan dengan subsektor yang lain. Subsektor ini memberikan kontribusi sebesar 17,43 persen, sedangkan subsektor perkebunan, peternakan, kehutanan dan perikanan hanya memberikan kontribusi masing-masing sebesar 4,88 persen, 1,73 persen, 4,29 persen, dan 7,18 persen pada tahun 2010.

Subsektor tanaman bahan makanan atau tanaman pangan menghasilkan berbagai macam produk tanaman, yaitu tanaman padi dan palawija (jagung, kedelai, ubi kayu, ubi jalar, kacang tanah, dan kacang hijau). Padi merupakan tanaman nomor satu di Indonesia dilihat dari jumlah tanaman pangan yang diproduksi. Hal ini disebabkan oleh masih besarnya ketergantungan masyarakat dalam mengkonsumsi beras dan menjadikan beras sebagai makanan pokok utama di Indonesia. Perkembangan hasil produksi tanaman padi dalam sektor pertanian Indonesia terlihat pada Gambar 1.

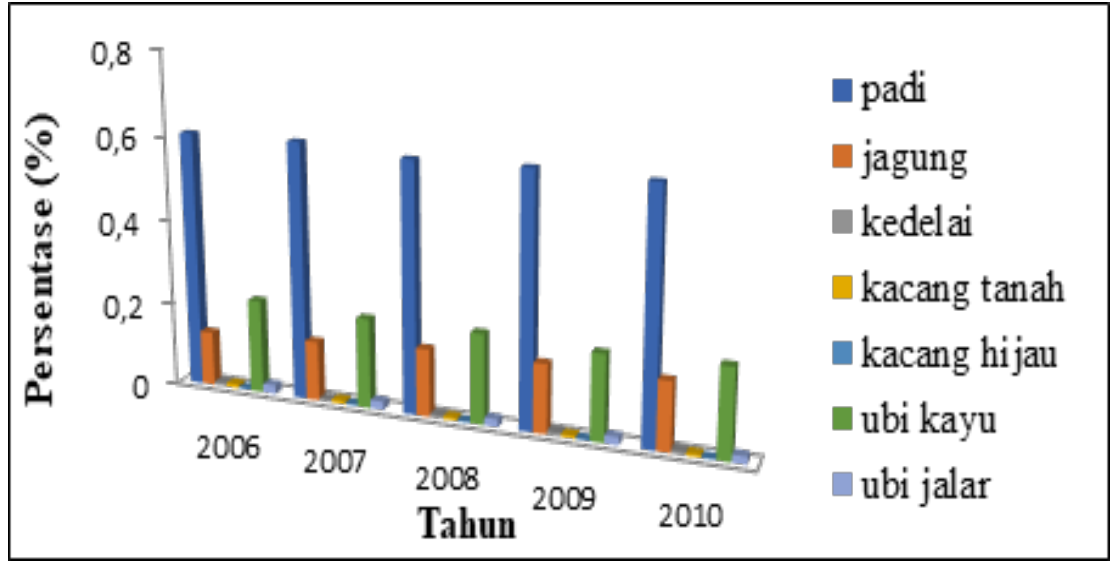

Sumber: BPS (2011)

Gambar 1: Hasil Produksi Pertanian di Indonesia berdasarkan Jenis Tanaman Pangan Tahun 2006-2010

Tingginya produksi tanaman padi belum mampu mengurangi permasalahan ketahanan pangan di Indonesia. Ketersediaan beras di Indonesia belum mencukupi kebutuhan beras yang dikonsumsi oleh masyarakat tanpa adanya impor beras dari negara lain. Menurut IFPRI (2011), Indonesia mengalami peningkatan impor beras sebesar $50 \%$ dan mengalami penurunan ekspor beras sebesar 63\% pada tahun 2006-2010.

Dinas Pertanian dan Badan Ketahanan Pangan telah melakukan sosialisasi mengenai diversifikasi pangan, namun hal tersebut belum dapat mengubah budaya masyarakat Indonesia terhadap konsumsi beras secara efektif. Dinas Pertanian juga melakukan inovasi Pengelolaan Tanaman Terpadu (PTT) untuk meningkatkan hasil produksi padi di setiap provinsi sebagai opsi lain dalam menyelesaikan masalah ketahanan pangan. 
Pengembangan teknik bercocok tanam serta teknologi terbukti dapat meningkatkan kuantitas produksi tanaman padi. Menurut BPS (2011b), produksi padi Indonesia adalah sebesar 54.454.937 ton pada tahun 2006 dan meningkat menjadi 66.469.394 ton pada tahun 2010. Hal ini menunjukkan bahwa produksi padi Indonesia mengalami peningkatan sebesar 22\% pada tahun 2010 dibandingkan dengan produksi padi pada tahun 2006. Penyumbang terbanyak hasil pertanian tanaman padi pada tahun 2010 didominasi oleh provinsi-provinsi yang berada di Pulau Jawa. Provinsi Jawa Timur merupakan penghasil tanaman padi terbanyak kedua di Pulau Jawa setelah Jawa Barat dengan kontribusi yaitu sebesar $32,01 \%$ atau $17,51 \%$ secara nasional.

Upaya peningkatan hasil produksi tanaman padi oleh pemerintah memiliki berbagai tantangan. Tantangan pertama adalah perubahan iklim. Salah satu dampak signifikan yang ditimbulkan oleh adanya perubahan iklim adalah perubahan sistem hidrologi. Perubahan iklim mengakibatkan tidak tetapnya musim kemarau dan musim hujan tiap tahun di Indonesia. Musim hujan tidak lagi terjadi secara tepat pada bulan Oktober sampai April dan musim kemarau pada bulan April sampai dengan Oktober (RECOFTC, 2012).

Tantangan berikutnya adalah ketersediaan air. Peranan air dalam sektor pertanian sangat penting, diantaranya air merupakan input utama untuk pertanian (Haryanto dkk., 2009). Sektor pertanian adalah pengguna air tertinggi (69\%) dibandingkan dengan industri (21\%) dan rumah tangga (10\%) (FAO, 2002). Pertanian di Indonesia umumnya mengandalkan sumber air dari air tanah dan air permukaan atau irigasi. Indonesia memiliki karakteristik dimana 75\% dari total aliran permukaan tersedia pada musim hujan yang berdurasi enam bulan, sementara $25 \%$ sisanya berada pada musim kemarau yang berlangsung selama enam bulan.

Tantangan ketiga yang dihadapi oleh sektor pertanian adalah laju pertumbuhan penduduk yang cukup tinggi di Indonesia. Berdasarkan hasil sensus penduduk yang dilakukan setiap 10 tahun, laju pertumbuhan penduduk Indonesia tahun 2000 - 2010 adalah sebesar 1,49 persen per tahun (BPS, 2010). Berdasarkan BKP (2012), pertumbuhan penduduk di Jawa Timur dari tahun 2008 sampai dengan 2011 sebesar rata-rata 1,5\% per tahun. Pertumbuhan penduduk yang tinggi membawa konsekuensi pada kebutuhan bahan makanan, khususnya padi yang semakin meningkat.

Ketiga tantangan tersebut menjadi permasalahan rumit dalam sektor pertanian. Di satu sisi, sektor pertanian diharapkan dapat memenuhi kebutuhan pangan masyarakat yang semakin meningkat, sedangkan di sisi yang lain sektor pertanian menghadapi jumlah sumber daya air yang tetap atau bahkan menurun akibat adanya perubahan iklim. Kebutuhan air untuk sektor domestik/rumah tangga yang semakin meningkat akibat meningkatnya jumlah penduduk dalam suatu wilayah secara otomatis mengubah alokasi kebutuhan air pertanian. Tabel 1 menunjukkan bahwa penggunaan air permukaan untuk sektor rumah tangga mengalami peningkatan sebesar $4 \%$, sedangkan untuk pertanian dan industri mengalami penurunan sebesar masing-masing $0,2 \%$ dan $37 \%$. Hal ini membuktikan bahwa penggunaan air di masing-masing sektor didasarkan pada kuantitas penggunanya.

Tabel 1: Pemanfaatan Volume Air Permukaan di Jawa Timur Tahun 2008-2011

\begin{tabular}{ccc}
\hline Kebutuhan & $\mathbf{2 0 0 8}$ & $\mathbf{2 0 1 1}$ \\
\hline Domestik & $5.364,07$ & $5.735,82$ \\
\hline Pertanian & $15.225,22$ & $15.187,83$ \\
\hline Industri & 331,72 & 206,85 \\
\hline
\end{tabular}

Sumber: Dinas PU Pengairan (2011) 
Dalam menghadapi ketiga tantangan yang telah dijelaskan, kontribusi dan peran infrastruktur lahan dan air sangat penting untuk meningkatkan produksi padi dalam sektor pertanian, namun infrastruktur lahan dan air semakin menambah beban pemerintah dalam menjaga stabilitas ketersediaan serta distribusi air. Perkembangan sistem irigasi yang lambat semakin menambah sulitnya pengawasan terhadap kuantitas air yang disalurkan ke sawah dan ladang. Pasokan air irigasi untuk lahan pertanian yang dapat dijamin ketersediannya hanya seluas 800.000 hektar dari 7,2 juta hektar. Hal ini membuktikan bahwa lahan irigasi di Indonesia sangat rentan terhadap faktor aliran sungai musiman dan curah hujan (Ditjen SDA, 2011). Kontrol yang kurang dari pemerintah dapat menyebabkan gagal panen dikarekan banjir dan kekeringan.

Provinsi Jawa Timur memiliki potensi sumber daya air sebesar 56,5 miliar $\mathrm{m}^{3}$ di tahun 2010 dan 55,8 miliar $\mathrm{m}^{3}$ di tahun 2011. Dengan potensi cadangan air permukaan yang melimpah, seharusnya provinsi Jawa Timur dapat mengaloksikan ketersediaan air secara tepat, khususnya pada saat musim kemarau. Namun, yang terjadi adalah buruknya sistem kontrol pemerintah menyebabkan masih banyak daerah pertanian di Jawa Timur yang rawan terhadap kekeringan. Menurut Direktorat Pengairan dan Irigasi (2006), kekeringan adalah saat dimana total kebutuhan air untuk berbagai sektor lebih besar daripada jumlah air yang tersedia untuk mencukupi kebutuhan tersebut.

Berdasarkan kondisi yang telah dijelaskan sebelumnya, maka diperlukan adanya perhitungan mengenai kebutuhan air pada sektor pertanian. Analisis penggunaan air dengan metode water footprint merupakan salah satu metode untuk mengetahui kebutuhan air aktual dalam proses produksi tanaman padi. Water footprint adalah kebutuhan air yang digunakan untuk memproduksi barang (padi) yang dikonsumsi oleh masyarakat di suatu daerah (Bulsink dkk., 2010).

Masalah lain terkait dengan sumber daya air di Indonesia dan negara sedang berkembang pada umumnya adalah bahwa air dianggap sebagai sumber common resource. Pada kondisi tersebut, nilai air tidak dapat ditentukan sebab tidak ada pasar yang menciptakan harga air. Di sisi lain, kebijakan penentuan harga air sangat penting dalam pengelolaan sumber daya air, terutama terkait dengan alokasi penggunaan air yang optimal (Fauzi, 2006). Namun demikian, dewasa ini telah berkembang berbagai metode valuasi ekonomi untuk mengestimasi nilai air pada sektor pertanian, diantaranya residual imputation approach, hedonic approach, dan alternative cost approach (Young, 1996).

Estimasi kebutuhan dan nilai air dapat mengurangi kendala yang berhubungan dengan pengalokasian dan pengawasan terhadap kuantitas air untuk irigasi. Oleh sebab itu, penelitian ini bertujuan untuk mengestimasi besarnya water footprint untuk produksi tanaman padi di kabupaten/kota Provinsi Jawa Timur, mengestimasi volume air yang dibutuhkan dalam produksi tanaman padi di kabupaten/kota Provinsi Jawa Timur, dan mengestimasi nilai sumber daya air dalam proses produksi tanaman padi di Jawa Timur. Periode yang akan dikaji dalam penelitian ini adalah tahun $2008-2011$.

\section{Telaah Literatur}

\section{Water Footprint}

Water footprint (WF) merupakan indikator penggunaan air dalam aktivitas manusia. Konsep water footprint diperkenalkan pertama kali oleh Hoekstra pada tahun 2002. Hoekstra membagi fungsi water footprint menjadi dua bagian, yaitu water footprint untuk aktivitas produksi dan water footprint untuk aktivitas konsumsi. Water footprint untuk aktivitas produksi merupakan penjumlahan penggunaan air selama proses produksi suatu barang. Water foot- 
print untuk aktivitas konsumsi dapat dijelaskan sebagai jumlah penggunaan air dari seluruh produk barang yang dikonsumsi oleh konsumen (Hoekstra dkk., 2011).

Pendekatan water footprint dalam menghitung kebutuhan air selama proses produksi dinilai sangat komprehensif atau bersifat detail dan menyeluruh. Sifat detail dari water footprint adalah adanya pembagian air menjadi tiga indikator yaitu air biru (blue water), air hijau (green water), dan air abu-abu (grey water), sedangkan sifat menyeluruh menunjukkan bahwa perhitungan dilakukan secara kumulatif dari masing-masing proses dimana proses produksi padi memiliki empat fase pertumbuhan, yaitu fase tanam, fase vegetatif, fase reproduktif/ generatif, dan fase pemasakan.

Pembagian air biru, air hijau, dan air abu-abu didasarkan pada sumber ketersediaan dan fungsi air. Air biru merupakan air permukaan seperti sungai, danau, waduk, embung; sedangkan air hijau merupakan air yang berasal dari air hujan. Air abu-abu dijadikan sebagai indikator terakhir untuk mengestimasi nilai polusi yang disebabkan oleh adanya aktivitas pertanian.

Air biru pada umumnya lebih tersedia sehingga memiliki biaya oportunitas yang lebih tinggi dibandingkan dengan air hijau yang cenderung tersedia pada saat musim hujan. Falkenmark (2003) dan Rockstrom (2003) menjelaskan bahwa memasukkan perhitugan penggunaan air hijau untuk mengurangi rekayasa terhadap perhitungan total water footprint, dimana air hijau selalu di substitusikan dengan air biru, menyebabkan tidak bernilainya air hijau. Pendekatan water footprint dapat diformulasikan dalam:

$$
W F P=I W F P+E W F P
$$

Water footprint (WFP) didapat dari penjumlahan antara internal water footprint (IWFP) dan external water footprint (EWFP). IWFP merupakan jumlah penggunaan air yang dibutuhkan dalam memproduksi tanaman padi di daerah observasi yang dikonsumsi oleh masyarakat setempat. EWFP merupakan jumlah penggunaan air yang dibutuhkan oleh tanaman padi yang berasal dari luar daerah observasi untuk dikonsumsi oleh masyarakat daerah observasi.

Blue water footprint adalah indikator penggunaan dari air biru (air permukaan dan air tanah). Menurut Hoekstra dkk. (2011), penggunaan tersebut meliputi 4 komponen, yaitu evaporasi air, air yang digunakan untuk memproduksi suatu barang, air yang telah digunakan tidak kembali ke daerah tangkapan yang sama seperti air yang telah digunakan mengalir ke daerah tangkapan lain atau ke laut, dan air tidak kembali dalam periode yang sama. Proses perhitungan blue water footprint dapat diformulasikan sebagai berikut:

$$
W F_{\text {biru }}=B W E+B W I+L R
$$

Di mana:

$\mathrm{WF}_{\text {biru }}$ : Blue water footprint

BWE : Tingkat evaporasi air biru

BWI : Jumlah air biru yang terkandung di dalam produk

LR : Jumlah air biru yang berada di suatu area/lahan yang digunakan untuk prosesproduksi

Green water footprint adalah volume air hujan yang digunakan selama proses produksi. Dalam prosesnya, green water footprint dapat diformulasikan sebagai:

$$
W F_{h i j a u}=B W E+B W I
$$


Di mana:

$\mathrm{WF}_{\text {hijau }}:$ Green water footprint

BWE : Tingkat evaporasi air hijau

BWI : Jumlah air hijau yang terkandung di dalam produk

Air abu-abu dihitung sebagai volume air yang dibutuhkan untuk mencairkan polutan yang ada, sehingga kualitas air untuk kebutuhan irigasi pertanian masih berada dalam standar kualitas air yang telah ditetapkan. Grey water footprint dapat dihitung dengan formula:

$$
W F_{a b u-a b u}=\frac{L}{C_{\max }-C_{n a t}}
$$

Di mana:

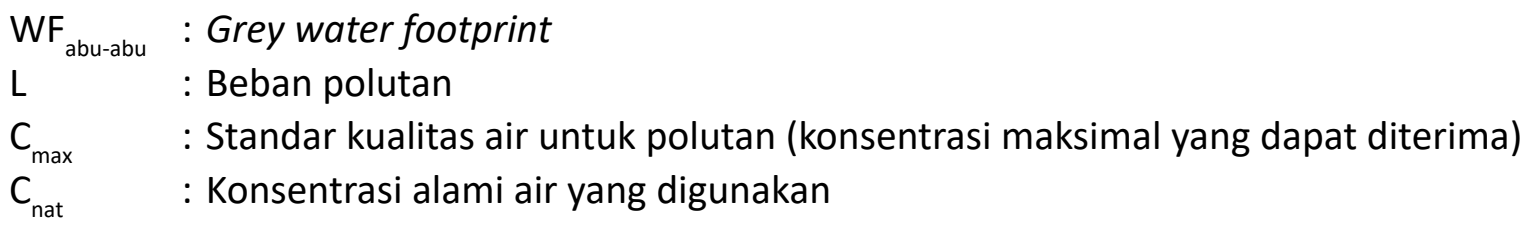

\section{Nilai Air}

Nilai air pada umumnya dibedakan menjadi dua bagian yaitu nilai guna (use value) dan nilai non-guna (non-use value). Menurut Agudelo (2001), nilai guna dibedakan dalam tiga kategori, yaitu berdasarkan perlakuan, lokasi, dan peran dalam ekonomi. Berdasarkan perlakuan, nilai air dapat dibedakan menjadi barang yang memiliki nilai konsumtif dan nilai non-konsumtif. Berdasarkan lokasi, air dibedakan menjadi dua yaitu instream dan offstream. Nilai instream ditujukan pada air yang berada dalam aliran sungai dan bergantung pada karakter aliran tersebut, sedangkan nlai offstream dapat diartikan sebagai air yang tidak berada dalam aliran sungai. Berdasarkan peran dalam ekonomi, air diklasifikasikan ke dalam barang antara dan barang akhir.

Air juga memiliki nilai non-guna. Nilai non-guna air ditempatkan dalam eksistensi terhadap bentuk fisik, biologi, ataupun budaya, sehingga nilai non-kegunaan air tidak dapat dijelaskan secara terperinci. Nilai non-guna air juga dipaparkan oleh Hydraulics dalam Agudelo (2001), bahwa air sebagai nilai budaya, sejarah dan warisan, nilai geomorfologi, dan nilai keindahan.

Pendapat lain mengenai nilai air juga dijelaskan oleh Smith. Menurut Smith, barang mempunyai dua nilai. Pertama, nilai guna (value in use); kedua, nilai tukar (value in exchange). Perbedaan dalam kedua konsep tersebut diilustrasikan dalam paradoks air-berlian (diamond-water paradox). Air yang memiliki nilai tinggi dalam penggunaan, memiliki nilai (harga) yang rendah dalam pertukaran, sedangkan berlian yang nilai gunanya rendah, memiliki nilai tukar yang tinggi (Deliarnov, 2007).

Penjelasan mengenai nilai air baik dalam nilai guna dan non-guna menjadikan air sebagai barang ekonomi, sehingga penggunaan air dapat dilibatkan dalam perhitungan suatu suatu aktivitas ekonomi. Klasifikasi nilai air membantu para ekonom untuk merancang suatu metode dalam menghitung nilai air sebagai komoditas dalam banyak kegunaan. Turner dkk. (2004) menjelaskan bahwa perhitungan nilai air sangat penting untuk beberapa alasan, seperti strategi pembangunan nasional, modifikasi perhitungan pendapatan nasional, penetapan prioritas, bahan evaluasi suatu kebijakan atau program pemerintah, serta valuasi ekonomi dan pembangunan berkelanjutan. 


\section{Valuasi Ekonomi Sumber Daya Air}

Valuasi ekonomi sumber daya air dapat dilaksanakan dengan adanya aktivitas manusia/penduduk untuk memanfaatkan air sesuai jenis kebutuhan di suatu daerah atau kawasan. Tujuan dari valuasi ekonomi sumber daya air adalah untuk mengetahui potensi dan dampak yang akan terjadi dengan adanya kegiatan, dan pada akhirnya merujuk pada alokasi dan efesiensi penggunaan sumber daya air (Field dan Olewiler, 2002). Valuasi ekonomi air dapat dilakukan dalam dua pendekatan yaitu pendekatan primer dan sekunder.

Metode primer menitik-beratkan pada keaslian data yang digunakan, dalam arti data tersebut didapat langsung dari objek yang diobservasi atau dari instansi yang berwenang secara langsung. Metode primer dibagi kedalam 3 kelompok yaitu penaksiran nilai bergantung informasi pasar, penaksiran nilai ditinjau dari air sebagai barang antara, dan penaksiran nilai air sebagai barang jadi (Agudelo, 2001).

Menurut Young (1996), terdapat tiga pendekatan yang lazim digunakan untuk melakukan valuasi air atau mengestimasi nilai air, yaitu residual imputation approach (RIA), hedonic approach (HA), dan the alternative cost approach (ACA). Kesesuaian penerapan masing-masing teknik atau pendekatan bergantung pada substansi permasalahan yang dihadapi. Metode RIA merupakan metode yang sering digunakan untuk mengetahui harga suatu barang khususnya air irigasi. Pendekatan HA digunakan untuk mengestimasi nilai implisit air pada suatu produk dan mengkaji hubungan antara karakteristik yang dihasilkan dengan permintaan barang dan jasa. Pendekatan ACA didasarkan pada sudut pandang willingness to pay (WTP) untuk suatu barang atau jasa publik tidak lebih besar daripada biaya yang dibutuhkan untuk pengadaan barang dan jasa tersebut apabila menggunakan proses atau teknologi yang lain.

Metode sekunder merupakan metode penaksiran nilai air menggunakan acuan dari hasil penelitian yang pernah dilakukan. Pendekatan yang dilakukan pada metode sekunder dinamakan pendekatan benefit transfer. Menurut Unsworth dan Petersen (1995), pendekatan ini memiliki dua syarat bagi penelitian yang digunakan sebagai acuan, yaitu kualitas dari penelitian yang digunakan dimana penelitian sebelumnya telah diakui oleh lembaga penelitian (Science Direct, JSTOR, dll.) ataupun telah dipublikasikan oleh institusi/organisasi yang berwenang (FAO, UNESCO, dll.), dan memiliki kesamaan sumber daya alam dan tujuan yang digunakan antara penelitian yang di replikasikan dengan penelitian yang akan dilakukan.

Benefit transfer memiliki beberapa tahapan sebagai uji validitas yang diperlukan agar peneliti tidak salah mengimplementasikan metode yang digunakan. Tahapan tersebut meliputi identifikasi sumber daya alam yang diteliti, identifikasi relevansi penelitian yang telah dilakukan, melakukan evaluasi terhadap penelitian yang telah dilakukan, dan penerapan benefit transfer untuk melakukan replika baik penerapan hasil perhitungan, fungsi yang digunakan, data, maupun model yang digunakan.

Menurut Navrud (2009), terdapat 2 pendekatan utama pada metode benefit transfer. Pendekatan tersebut adalah unit value transfer dan function transfer. Unit value transfer terdiri dari simple unit value transfer dan unit value transfer with adjustment for income differences. Function transfer terdiri dari benefit function transfer dan meta analysis. Pendekatan simple unit transfer mengasumsikan bahwa rata-rata pendapatan per kapita lokasi penelitian sebelumnya sama dengan rata-rata pendapatan per kapita lokasi yang akan diteliti. Unit value transfer with adjustment for income differences adalah pendekatan yang digunakan dengan melakukan penyesuaian terhadap tingkat harga antara daerah pada penelitian sebelumnya dengan daerah yang akan diteliti atau tingkat harga pada tahun penelitian sebelumnya dengan tahun yang akan diteliti. Benefit function transfer secara konseptual lebih menarik dibanding- 
kan dengan pendekatan unit value transfer karena lebih banyak informasi yang akan diperoleh dari transfer fungsi yang dilakukan. Meta analysis merupakan kombinasi dari benefit function transfer karena pendekatan meta analysis mengumpulkan dan menyimpulkan satu fungsi dari beberapa penelitian sebelumnya.

\section{Penelitian Terdahulu}

Berbagai penelitian berkaitan dengan perhitungan water footprint untuk tanaman pangan antar negara maupun antar provinsi telah dilakukan. Perhitungan tersebut dilakukan di berbagai negara di bagian Eropa dan Amerika, serta Indonesia. Penelitian yang telah dilakukan menunjukkan bahwa padi merupakan tanaman pangan yang membutuhkan air terbanyak dibandingkan dengan tanaman pangan yang lain. Penelitian mengenai water footprint di antaranya telah dilakukan oleh Kuo dkk. (2006) dan Bulsink dkk. (2010).

Penelitian Kuo dkk. (2006) menggunakan koefisien tanaman dan input data dari model manajemen irigasi CROPWAT untuk mengestimasi kebutuhan air irigasi tanaman padi dan tanaman pangan lain di Chianan, Taiwan. Pendekatan yang digunakan adalah metode perhitungan Penman-Monteith yang telah direkomendasikan oleh Food and Agriculture Organization (FAO) dengan bantuan perangkat lunak CROPWAT. Penelitian tersebut menunjukkan bahwa padi merupakan tanaman pangan yang memiliki tingkat evapotranspirasi dan koefisien tanaman tertinggi dibandingkan dengan tanaman jagung, kedelai, dan gandum.

Penelitian Bulsink dkk. (2010) dilakukan untuk menganalisis kebutuhan penggunaan air tanaman pangan di 30 provinsi di Indonesia. Penelitian tersebut menggunakan metode perhitungan matematika untuk mengetahui jumlah total kebutuhan tanaman pangan terhadap sumber daya air. Variabel yang digunakan dalam penelitian tersebut adalah kepadatan penduduk, iklim, koefisien masing-masing tanaman, konsumsi air, kuantitas produksi tanaman pangan, tingkat konsumsi masyarakat terhadap masing-masing tanaman. Hasil dari penelitian menunjukkan bahwa konsumsi air untuk tanaman pangan di Indonesia adalah $1131 \mathrm{~m}^{3}$ / kapita/tahun. Provinsi dengan tingkat konsumsi air paling tinggi di Indonesia untuk tanaman pangan adalah Provinsi Kalimantan Tengah, sedangkan konsumsi air terendah adalah Provinsi Jawa Timur. Faktor-faktor yang mempengaruhi water footprint adalah tingkat konsumsi, pola konsumsi, iklim, dan sistem/praktik pertanian. Pola konsumsi di tiap provinsi diasumsikan sama oleh peneliti karena padi/beras merupakan bahan makanan utama masyarakat Jawa Timur, sehingga faktor yang berpengaruh terhadap water footprint adalah iklim, sistem pertanian, dan tingkat konsumsi.

Penelitian mengenai perhitungan nilai air pada sektor tanaman pangan telah banyak dilakukan. Hasil dari perhitungan nilai air berfungsi sebagai acuan pemerintah untuk membuat suatu kebijakan dalam pengalokasian air dengan kendala ketersediaan air. Penelitan mengenai nilai air di antaranya telah dilakukan oleh Rodgers dan Petra (2005) dan Aylward dkk. (2010).

Rodgers dan Petra (2005) melakukan penelitian untuk menghitung nilai air dalam subsektor tanaman pangan. Penelitian tersebut menggunakan metode volumetric pricing yang menggambarkan kuantitas air yang dikonsumsi oleh irigasi. Indikator yang digunakan oleh peneliti untuk menghitung harga air adalah biaya untuk jasa irigasi (biaya pengoperasian dan perawatan) dan biaya iuran yang telah ditetapkan oleh HIPPA (Himpunan Petani Pemakai Air). Penelitian dilakukan di daerah DAS Brantas Jawa Timur. Data yang digunakan merupaka data yang bersumber dari IFPRI tahun 2000. Obyek penelitian meliputi 480 rumah tangga petani yang berada di daerah hulu, tengah, dan hilir dari DAS Brantas. Penelitian nilai air yang dilakukan merupakan air irigasi yang diperuntukkan pada empat jenis tanaman pangan dominan 
di daerah observasi. Hasil penelitian menunjukkan bahwa rata-rata harga air tertinggi ke terendah secara berturut-turut adalah: jagung $\left(\mathrm{Rp} 830 / \mathrm{m}^{3}\right)$, kacang tanah (Rp 525/ $\left.\mathrm{m}^{3}\right)$, kedelai $\left(\operatorname{Rp} 389 / \mathrm{m}^{3}\right)$, dan padi $\left(\operatorname{Rp} 298 / \mathrm{m}^{3}\right)$.

Aylward dkk. (2010) melakukan penelitan nilai air terhadap sektor pertanian, industri, dan rumah tangga. Peneliti menggunakan metode benefit transfer dalam mengestimasi nilai air. Data yang digunakan merupakan data berdasarkan penelitian-penelitian yang telah dilakukan. Peneliti menggunakan hasil dari 63 penelitian dengan 181 wilayah untuk mengestimasi nilai air dalam tiga sektor (pertanian, industri, dan rumah tangga) di empat benua yaitu Eropa, Afrika, Asia, dan Amerika Utara. Hasil dari penelitian tersebut berupa estimasi nilai air untuk sektor pertanian, industri, dan rumah tangga mmasing-masing sebesar $0,27 \$ / \mathrm{m}^{3}, 0,86 \$ / \mathrm{m}^{3}$, dan $0,59 \$ / \mathrm{m}^{3}$.

\section{Metode Penelitian}

Penelitian ini menggunakan pendekatan kuantitatif dengan model matematika. Model matematika digunakan untuk menghitung estimasi water footprint dan volume kebutuhan air tanaman padi di Jawa Timur menggunakan metode Penman-Montieth serta estimasi nilai air menggunakan metode benefit transfer. Pengolahan data dalam penelitian ini dilakukan dengan menggunakan perangkat lunak Excel dan CROPWAT.

Metode Penman-Montieth melingkupi tiga jenis indikator yang digunakan dalam mengukur total water footprint (WF) kabupaten/kota di Jawa Timur yang terdiri dari WF internal dan WF eksternal. Ketiga indikator tersebut adalah WF biru, WF hijau, dan WF abu-abu. Indikator-indikator tersebut memiliki variabel pembentuk. Variabel pembentuk dari WF hijau dan WF biru adalah evapotranspirasi, parameter tanaman padi, dan produksi. Variabel pembentuk dari indikator WF abu-abu yaitu air pelarut dan produksi. Model yang digunakan untuk menghitung water footprint adalah sebagai berikut:

Dimana:

$$
W F_{\text {total }}=W F_{\text {biru }}+W F_{\text {hijau }}+W F_{a b u-a b u}
$$

$$
\begin{array}{ll}
W_{\text {total }} & : \text { Total kebutuhan air } \\
W_{\text {biru }} & : \text { Water footprint biru } \\
W_{\text {hijau }} & : \text { Water footprint hijau } \\
\mathrm{WF}_{\text {abu-abu }} & : \text { Water footprint abu-abu }
\end{array}
$$

Metode benefit transfer digunakan untuk mengestimasi nilai air untuk tanaman padi di Jawa Timur. Kemudahan dari benefit transfer adalah diperbolehkannya menyadur hasil dari penelitian sebelumnya, sehingga variabel yang digunakan dalam penelitian ini sama persis dengan penelitian tersebut. Estimasi nilai air pada penelitian ini mengacu pada hasil penelitian Rodgers dan Petra (2005). Pendekatan yang digunakan adalah pendekatan Unit value transfer with adjustment for income differences. Nilai air diperoleh menggunakan rumus:

$$
V=P \times Q
$$

Dimana:

$\checkmark$ : Nilai air

$P$ : Harga air

Q : Kuantitas air

Harga air diperoleh dari persamaan berikut:

$$
F=P \times \frac{r_{n}}{r_{0}}
$$


Di mana:

F : Harga pada tahun yang diteliti.

P : Harga pada tahun dasar yang diketahui (2000).

$r_{0}$ : Tingkat harga tahun dasar yang diketahui.

$r_{n}$ : Tingkat harga tahun yang diteliti

Perubahan harga dihitung dengan menggunakan rumus:

Di mana:

$$
r=\text { deflator }=\frac{P D R B_{n}}{P D R B_{r}} \times 100
$$

PDRB $_{n}$ : Produksi Domestik Regional Bruto nominal dari subsektor tanaman pangan.

PDRB $_{r}$ : Produksi Domestik Regional Bruto riil dari subsektor tanaman pangan.

Definisi masing-masing variabel yang digunakan dalam penelitian ini adalah sebagai berikut:

\section{Water footprint}

Water footprint menunjukkan estimasi penggunaan air pada tanaman padi yang dikonsumsi oleh masyarakat di suatu daerah (Hoekstra dkk., 2011). Variabel water footprint didapat melalui persamaan (1) dan menggunakan satuan meter kubik per tahun ( $\mathrm{m}^{3} /$ tahun). Variabel water footprint dibentuk oleh indikator variabel Water footprint biru, hijau, dan abu-abu yang didapat dari persamaan:

$$
W F_{w}=\frac{C W U_{w}}{Y}, w=\text { jenis air }
$$

Di mana, CWU adalah volume penggunaan air untuk tanaman padi dan $Y$ adalah nilai produktivitas lahan. Polutan dalam pertanian timbul akibat adanya aktivitas dari pemupukan, pemberian pestisida dan insektisida. Dalam penelitian ini, peneliti menghiraukan pestisida dan insektisida dikarenakan data yang tidak tersedia, sehingga nilai pestisida dan insektisida dianggap 0.

\section{Evapotranspirasi}

Evapotranspirasi menunjukkan kondisi iklim yang dihitung menggunakan bantuan dari aplikasi CROPWAT. Variabel iklim meliputi tingkat kelembaban udara (\%), temperatur tiap daerah $\left({ }^{\circ} \mathrm{C}\right)$, kecepatan angin ( $\mathrm{km} /$ hari), intensitas cahaya matahari (\%), curah hujan (milimeter), dan lokasi masing-masing daerah (Allen dkk., 1998). Data yang digunakan merupakan data bulanan dari tahun 2008 - 2011. Satuan Evapotranspirasi adalah mm/hari. Nilai evapotranspirasi dapat dicari dengan menggunakan persamaan berikut:

$$
E T_{0}=\frac{0.408 \Delta\left(R_{n}-G\right)+\gamma \frac{900}{T+273} U^{2}\left(e_{s}-e_{a}\right)}{\Delta+\gamma\left(1+0.34 U_{2}\right)}
$$

Di mana:

$\mathrm{ET}_{0}$ : Evapotranspirasi tanaman ( $\mathrm{mm} /$ hari)

$\Delta \quad$ : Slope kurva tekanan uap air $\left(\mathrm{kPa} /{ }^{\circ} \mathrm{C}\right)$

$\mathrm{T} \quad$ : Rata-rata temperature udara $\left({ }^{\circ} \mathrm{C}\right)$

$\Gamma \quad$ : konstanta psychrometric $\left(\mathrm{kPa} /{ }^{\circ} \mathrm{C}\right)$

$e_{\mathrm{s}} \quad:$ Tekanan saturasi uap air (kPa) 
$\mathrm{R}_{\mathrm{n}} \quad$ : Radiasi pada permukaan tanaman $\left(\mathrm{MJ} / \mathrm{m}^{2} /\right.$ hari)

$\mathrm{G} \quad$ : Tingkat didih tanah $\left(\mathrm{MJ} / \mathrm{m}^{2} /\right.$ hari)

$\mathrm{U}_{2} \quad$ : Kecepatan angina $(\mathrm{m} / \mathrm{dt})$

$e_{\mathrm{a}} \quad:$ Tekanan uap air actual $(\mathrm{kPa})$

$e_{\mathrm{s}}-e_{\mathrm{a}}$ : Defisit tekanan uap air $(\mathrm{kPa})$

\section{Parameter tanaman padi}

Parameter tanaman (Kc) menunjukkan nilai parameter tanaman padi secara keseluruhan dalam proses produksi (Allen dkk., 1998). Kc bergantung pada jenis dan fase pertumbuhan tanaman. Tanaman padi memiliki empat fase yaitu fase tanam, vegetatif, reproduktif/generatif, dan pemasakan. Kc juga bergantung pada musim hujan dan kemarau. Nilai $\mathrm{K}_{\mathrm{c}}$ tersedia pada tabel.

Tabel 2: Koefisien Tanaman $\left(K_{c}\right)$

\begin{tabular}{ccc}
\hline \multicolumn{2}{c}{ Fase Tanaman } & \multirow{2}{*}{$\mathbf{K}_{\mathbf{c}}$} \\
\cline { 1 - 2 } Istilah Indonesia & Istilah CROPWAT & $0,30-1,20$ \\
\hline Tanam & Nursery Landprep & $0,50-1,10$ \\
\hline Vegetatif & Initial Development & 0,50 \\
\hline Generatif & Mid-season & $1,05-1,20$ \\
\hline Pemasakan & Late-season & $0,70-1,05$ \\
\hline
\end{tabular}

Sumber: Direktorat Pengairan dan Irigasi (2006)

4. Kuantitas produksi dan luas panen tanaman padi

Kuantitas produksi tanaman padi menunjukkan jumlah padi yang diproduksi dalam satuan ton dan luas panen tanaman padi dalam satuan hektar $(\mathrm{Ha})$ berdasarkan musim tanam. Provinsi Jawa Timur memiliki tiga musim tanam dalam satu tahun. Musim tanam pertama antara bulan Januari - April, musim tanam kedua antara bulan Mei-Agustus, musim tanam ketiga antara September - Desember.

\section{Konsumsi}

Konsumsi menunjukkan jumlah padi yang dikonsumsi oleh masyarakat di suatu daerah dalam satuan ton. Nilai konsumsi yang diperoleh dari Badan Ketahanan Pangan dalam satuan ton beras, sehingga harus dilakukan penyesuaian kedalam satuan ton padi. Berdasarkan Dinas Pertanian Provinsi Jawa Timur, nilai konversi padi (gabah kering giling) menjadi beras adalah $63,2 \%$ di tahun 2008 , sedangkan tahun $2009-2011$ sebesar $65 \%$.

\section{Nilai air}

Nilai air menunjukkan estimasi nilai air yang digunakan untuk sektor pertanian subsektor tanaman pangan khusus tanaman padi di Jawa Timur. Nilai air dihitung melalui persamaan (6). Satuan nilai dan harga air adalah rupiah.

\section{Jenis dan Sumber Data}

Jenis data yang digunakan dalam penelitian ini adalah data sekunder berupa data panel dari 29 kabupaten dan 9 kota di Jawa Timur pada tahun 2008 - 2011. Data luas area panen, jumlah produksi padi, jumlah konsumsi beras, jumlah penduduk dan lokasi masing-masing kabupaten/kota bersumber dari Badan Pusat Statistik (BPS), Badan Ketahanan Pangan (BKP) Provinsi Jawa Timur dan Dinas Pertanian Provinsi Jawa Timur meliputi. Data iklim yang meliputi curah hujan, intensitas cahaya matahari, kelembaban udara, kecepatan angin, dan temperatur bersumber dari Badan Meteorologi, Klimatologi, dan Geofisika (BMKG). 


\section{Hasil dan Pembahasan}

\section{Water Footprint}

Konsep water footprint memasukkan semua indikator air biru, hijau, dan abu-abu sebagai kebutuhan air tanaman padi. Estimasi perhitungan rata-rata water footprint adalah dengan membagi penggunaan air, baik air biru, hijau, maupun abu-abu, dengan produktivitas lahan. Hasil pembagian tersebut merupakan nilai water footprint dari masing-masing jenis air. Rata-rata water footprint untuk tanaman padi di Jawa Timur tahun 2008 - 2011 secara

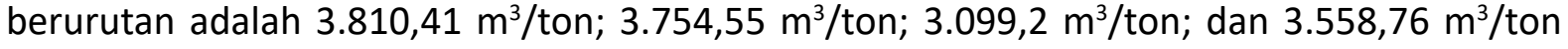
(gambar 2).

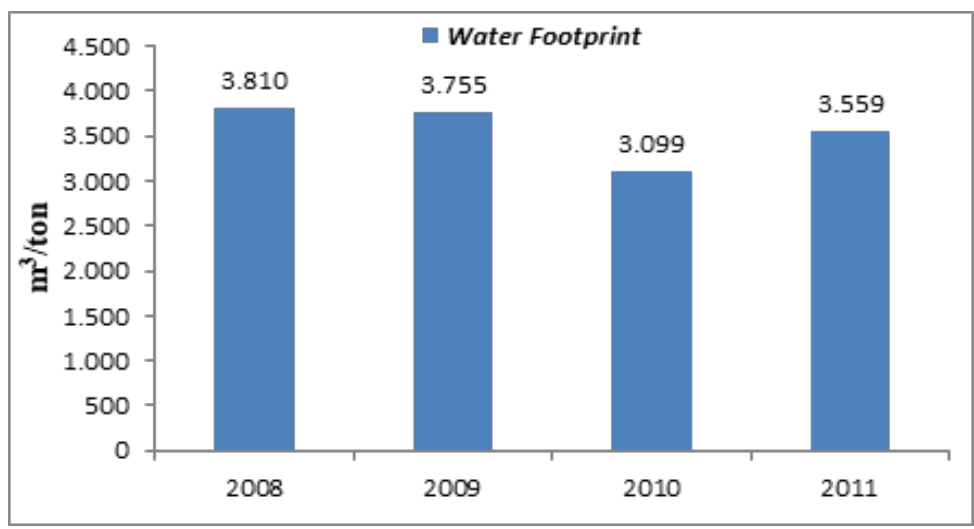

Sumber: hasil perhitungan CROPWAT

\section{Gambar 2: Rata-rata Water Footprint Jawa Timur Tahun 2008 - 2011}

Pada tahun 2008, terdapat 13 daerah administratif yang memiliki nilai water footprint di atas rata-rata water footprint provinsi. Pada tahun 2009, terjadi peningkatan daerah yang memiliki nilai di atas rata-rata, yaitu menjadi 20 daerah administratif. Pada tahun 2010 dan 2011, daerah dengan nilai WF diatas rata-rata yaitu 16 dan 17 daerah administratif.

Berdasarkan gambar 3, Kota Probolinggo adalah kota yang memiliki rata-rata WF tertinggi pada tahun 2008 dengan nilai WF sebesar $5.279 \mathrm{~m}^{3} /$ ton. Tingginya rata-rata nilai WF Kabupaten Probolinggo disebabkan oleh tingginya kontribusi penggunaan air biru sebesar $21.230 \mathrm{~m}^{3} / \mathrm{Ha}$ serta rendahnya tingkat produktivitas lahan yang hanya sebesar 4,51 ton/Ha. Pada tahun 2009, Kota Batu merupakan daerah yang memiliki rata-rata WF tertinggi dengan nilai sebesar $5.915 \mathrm{~m}^{3} /$ ton. Penyebab tingginya rata-rata WF Kota Batu adalah nilai air biru sebesar $20.718 \mathrm{~m}^{3} / \mathrm{Ha}$ dan air abu-abu sebesar $9.393 \mathrm{m3} / \mathrm{Ha}$, meskipun Kota Batu memiliki tingkat produktivitas lahan yang cukup tinggi sebesar 5,4 ton/Ha. Rata-rata WF tertinggi pada tahun 2010 dan 2011 adalah Kota Pasuruan dan Kota Blitar. Meskipun nilai air biru, hijau, dan abu-abu Kota Blitar (20.657 m³ $\mathrm{Ha}$ ) masih lebih rendah dari Kabupaten Sidoarjo $\left(23.455 \mathrm{~m}^{3}\right.$ / $\mathrm{Ha})$, namun Kabupaten Sidoarjo memiliki nilai produktivitas lahan yang lebih tinggi (5,49 ton/ $\mathrm{Ha}$ ) dibandingkan dengan Kota Blitar (3,63 ton/Ha).

Dalam penelitian ini, menurunnya nilai rata-rata water footprint di masing-masing daerah dipengaruhi oleh tiga faktor. Pertama adalah tingkat evapotranspirasi di masing-masing daerah yang dapat mempengaruhi kuantitas kebutuhan air biru dan hijau, kedua adalah jumlah penggunaan pupuk per hektar yang dapat mempengaruhi air abu-abu, dan ketiga adalah tingkat produktivitas lahan di masing-masing daerah yang menggambarkan efisiensi penggunaan air biru, hijau, dan abu-abu. Turunnya rata-rata water footprint dalam penelitian ini sesuai dengan hasil penelitian Hoekstra \& Chapagain (2006) dan Hoekstra dkk. (2011) yang menyimpulkan bahwa nilai water footprint dengan satuan $\mathrm{m}^{3} /$ ton dapat berkurang dengan 
berbagai cara, diantaranya adalah peningkatan produktivitas lahan, pengurangan penggunaan pupuk, dan perubahan iklim.

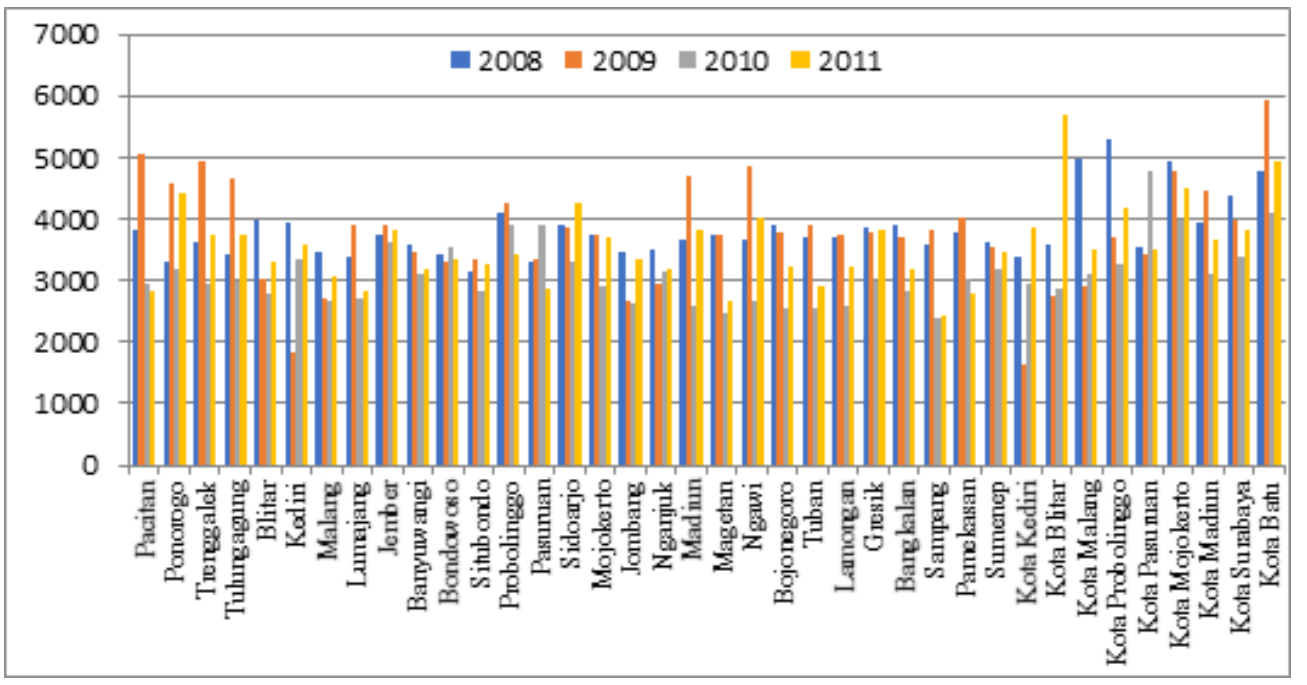

Sumber: Hasil Perhitungan CROPWAT

\section{Gambar 3: Rata-Rata Water Footprint Kabupaten/Kota Tahun 2008-2011 (m³/Ton)}

Nilai dari rata-rata water footprint selanjutnya digunakan untuk mengetahui nilai total water footprint di masing-masing daerah. Total water footprint menggambarkan volume kebutuhan air yang terkandung pada tanaman padi yang dikonsumsi oleh masyarakat di masing-masing daerah observasi. Nilai tersebut terdiri dari WF internal dan WF eksternal. Secara teknis, perhitungan total water footprint suatu daerah didapat dari penjumlahan antara perkalian rata-rata water footprint dengan hasil produksi padi yang dikonsumsi dan perkalian rata-rata WF dengan impor tanaman padi yang dikonsumsi.

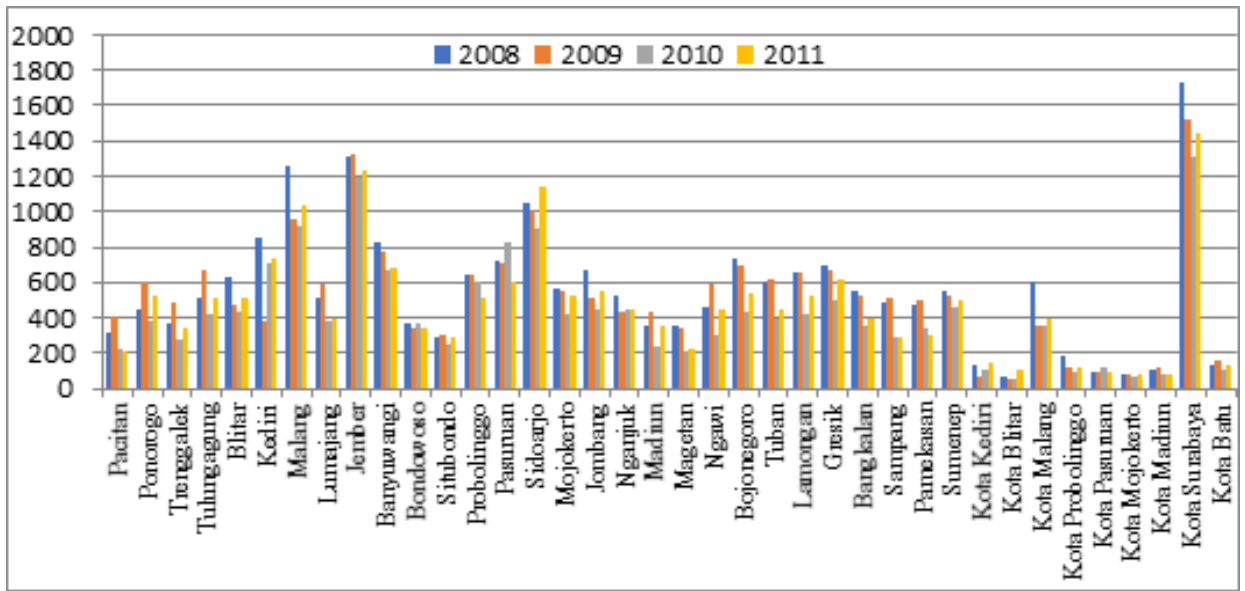

Sumber: Hasil Perhitungan

\section{Gambar 4: Total Water Footprint Kabupaten/Kota Tahun 2008-2011 (Juta m³)}

Berdasarkan Gambar 4, total water footprint tertinggi dari tahun 2008 sampai dengan 2011 berada di Kota Surabaya dengan nilai masing-masing sebesar 1.728,15; 1.522,35; 1.312,47; dan 1.447,07 juta $\mathrm{m}^{3}$, sedangkan total water footprint terendah pada tahun 2008 sampai dengan 2010 berada di Kota Blitar (71,26; 53,12; dan 53,33 juta $\mathrm{m}^{3}$ ) dan tahun 2011 di Kota Mojokerto $\left(74,05\right.$ juta $\left.\mathrm{m}^{3}\right)$. Tinggi rendahnya total water footprint dipengaruhi oleh jumlah konsumsi padi. Meskipun Kota Surabaya adalah kota dengan jumlah total water footprint tertinggi, hal tersebut tidak membuktikan bahwa Kota Surabaya adalah kota dengan tingkat WF per kapita tertinggi di Jawa Timur. WF per kapita tertinggi dari tahun 2008 hingga 2011 
secara berurutan berada di Kota Probolinggo, Kota Batu, Kota Pasuruan, dan Kota Blitar dengan tingkat nilai masing-masing sebesar 791,23; 861,89; 669,2; dan 776,21 m³/kapita. Hasil perhitungan tersebut mengindikasikan bahwa penduduk di Kota Probolinggo, Kota Batu, Kota Pasuruan, dan Kota Blitar masih memiliki ketergantungan yang tinggi terhadap tanaman padi sebagai bahan makanan utama.

\section{Kebutuhan Air untuk Tanaman Padi}

Kebutuhan air untuk tanaman padi adalah rata-rata water footprint suatu daerah dikalikan dengan jumlah produksi padi yang dihasilkan di daerah observasi. Berdasarkan perhitungan, kebutuhan air Provinsi Jawa Timur pada tahun 2008 hingga 2011 secara berurutan adalah $36.545,17$ juta $\mathrm{m}^{3} ; 40.004,35$ juta $\mathrm{m}^{3} ; 33.082,10$ juta $\mathrm{m}^{3}$; dan $34.021,319$ juta $\mathrm{m}^{3}$.

Total kuantitas tanaman padi sawah yang dihasilkan pada tahun 2008 hingga 2011 sebesar 10,01 juta ton; 10,74 juta ton; 11,12 juta ton; dan 10,02 juta ton. Mengacu pada gambar 5, terdapat perbedaan antara persentase pertumbuhan total kebutuhan air dengan persentase pertumbuhan total produksi padi sawah khususnya pada tahun 2010 dan 2011, dimana total produksi padi sawah pada tahun tersebut lebih besar dibandingkan dengan tahun 2008, namun volume air yang dibutuhkan lebih sedikit jumlahnya dibandingkan tahun 2008. Hal ini dikarenakan tinggi rendahnya kebutuhan air juga dipengaruhi oleh nilai rata-rata water footprint masing-masing daerah.

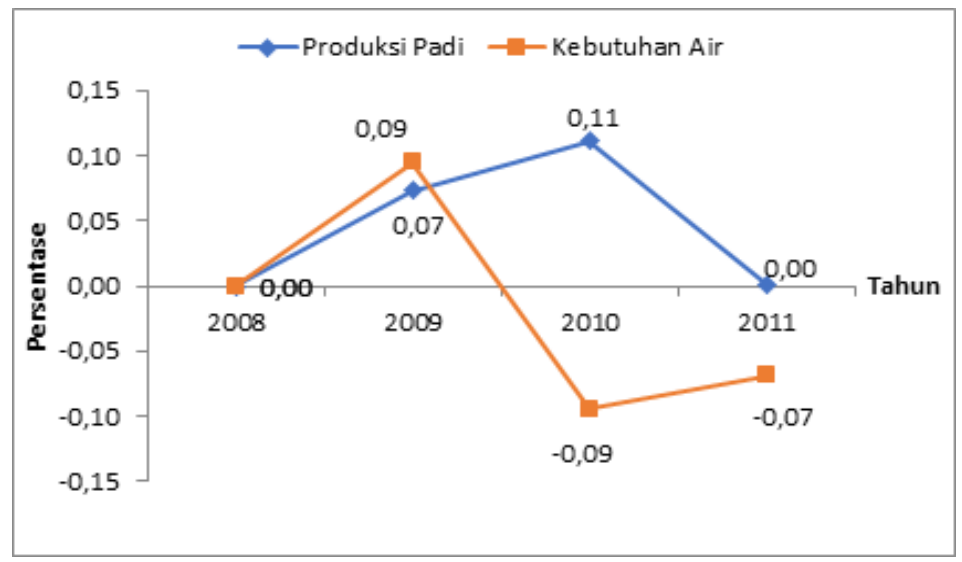

Sumber: Hasil Perhitungan

\section{Gambar 5: Pertumbuhan Kebutuhan Air dan produksi Padi Tahun 2008-2011}

Kebutuhan tertinggi volume air untuk tanaman padi sawah dari tahun 2008 hingga 2011 terdapat di Kabupaten Jember dengan volume masing-masing sebesar 2,88 miliar $\mathrm{m}^{3}$; 3,26 miliar $\mathrm{m}^{3} ; 3,07$ miliar $\mathrm{m}^{3}$; dan 3,1 miliar $\mathrm{m}^{3}$. Tingginya kebutuhan air di Kabupaten Jember disebabkan oleh tingginya produksi padi sawah yang dihasilkan (gambar 6). Volume kebutuhan air tertinggi kedua terdapat di Kabupaten Lamongan, yaitu berturut-turut sebesar 2,84

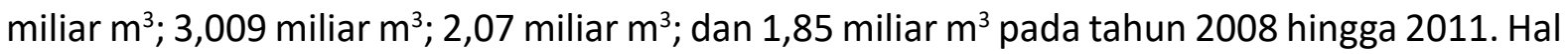
yang sama seperti Kabupaten Jember, tingginya volume kebutuhan air Kabupaten Lamongan disebabkan oleh tingginya produksi padi sawah yang dihasilkan.

Setelah mengetahui hasil perhitungan mengenai kebutuhan air irigasi untuk tanaman padi, maka dapat dilakukan perbandingan antara kebutuhan dengan alokasi air untuk irigasi yang telah ditetapkan oleh Dinas Pekerjaan Umum Pengairan. Hasil dari perbandingan tersebut digunakan untuk menilai apakah pemerintah telah melakukan pengalokasian air irigasi secara tepat atau tidak. 


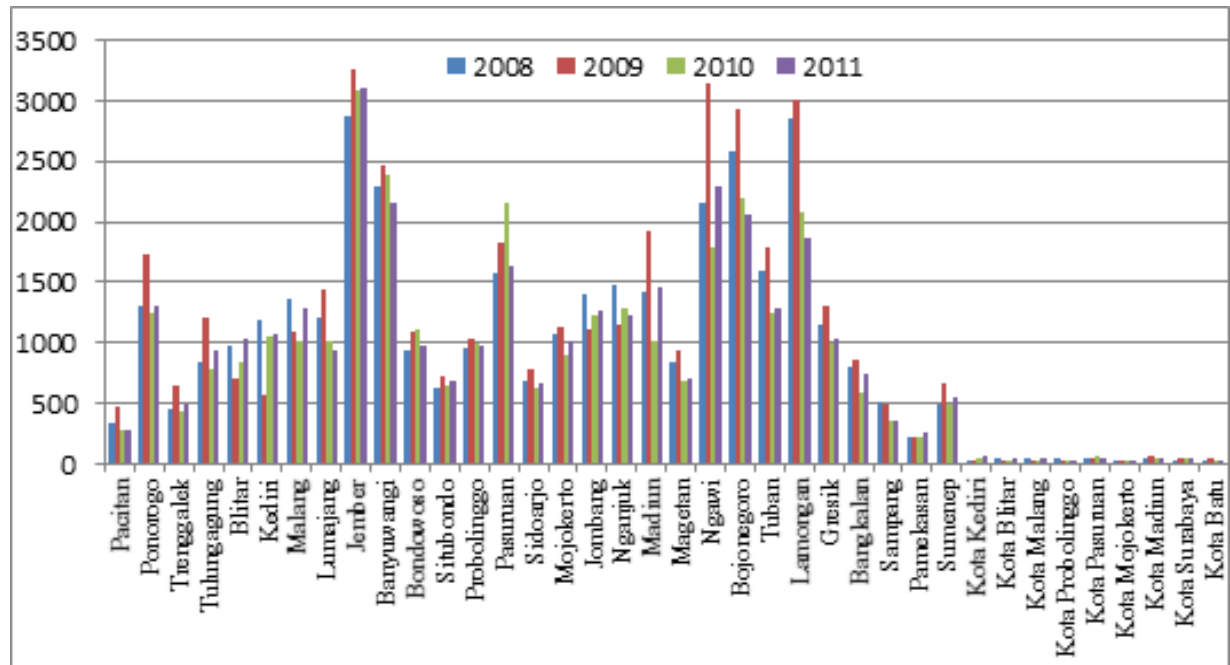

Sumber: Hasil Perhitungan

\section{Gambar 6: Kebutuhan Air Tanaman Padi Kabupaten/Kota Tahun 2008-2011 $\left(10^{6} \mathrm{~m}^{3}\right)$}

Mayoritas daerah di Jawa Timur pada dasarnya mengalami defisit air untuk subsektor tanaman padi (gambar 7). Pengertian defisit air adalah kebutuhan air lebih besar daripada alokasinya. Pada tahun 2008, daerah yang tidak mengalami defisit air adalah Kabupaten Pacitan, Kabupaten Banyuwangi, Kota Malang, Kota Probolinggo, Kota Pasuruan, Kota Madiun, dan Kota Batu. Pada tahun 2009, daerah yang tidak mengalami defisit air adalah Kabupaten Lumajang, Kabupaten Banyuwangi, Kota Malang, Kota Probolinggo, Kota Pasuruan dan Kota Batu. Tahun 2010, daerah yang tidak mengalami defisit air adalah Kabupaten Pacitan, Kabupaten Lumajang, Kabupaten Banyuwangi, Kota Malang, Kota Probolinggo, Kota Madiun, dan Kota Batu. Tahun 2011, terdapat 7 daerah yang tidak mengalami defisit air, yaitu Kabupaten Pacitan, Kabupaten Lumajang, Kabupaten Banyuwangi, Kota Malang, Kota Probolinggo, Kota Pasuruan, dan Kota Batu.

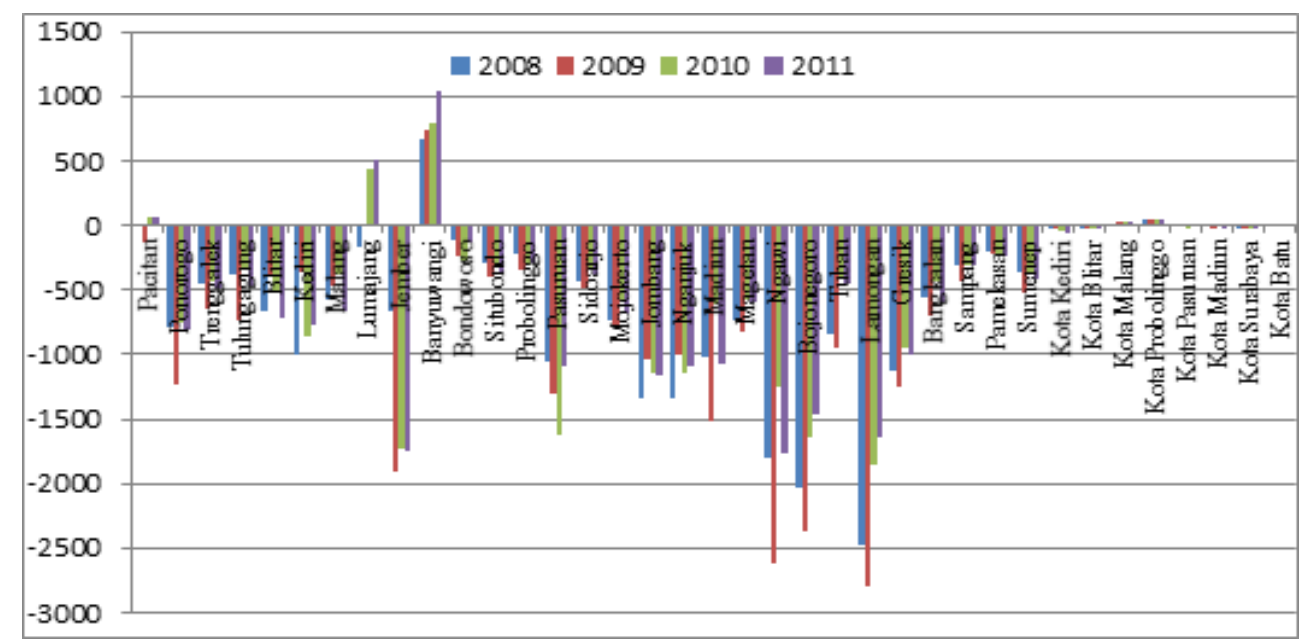

Sumber: Hasil Perhitungan

Gambar 7: Surplus/Defisit Volume Air untuk Tanaman Padi Kabupaten/Kota Tahun 2008$2011\left(10^{6} \mathrm{~m}^{3}\right)$

Terjadinya perbedaan yang tinggi antara alokasi dan kebutuhan air disebabkan oleh acuan yang digunakan pemerintah tiap tahunnya yang hanya sebesar 1-1,2 liter/detik tiap hektar atau setara dengan $1.715 \mathrm{~m}^{3} / \mathrm{Ha}$ per tahun, sedangkan berdasarkan perhitungan water footprint yang mengacu pada tingkat evapotranspirasi suatu daerah menghasilkan nilai kebu- 
tuhan air yang berbeda tiap tahunnya. Perbedaan tersebut dipengaruhi oleh perubahan iklim yang meliputi curah hujan, intensitas matahari, kelembaban udara, kecepatan angin sehingga hasil perhitungan kebutuhan air rata-rata dari tahun $2008-2011$ adalah $3.556 \mathrm{~m}^{3} / \mathrm{Ha}$ per tahun. Perbedaan nilai kebutuhan air adalah dua kali lebih besar dari alokasi yang ditetapkan.

Berdasarkan hasil perbandingan antara nilai kebutuhan dan nilai alokasi, maka daerah yang memiliki defisit kebutuhan air belum tentu mengalami kekeringan, seperti Kabupaten Nganjuk yang defisit air $-1.335,25$ juta $\mathrm{m}^{3}$ ternyata tidak mengalami gagal panen akibat kekeringan, namun hal tersebut dapat mempengaruhi tingginya peluang kekeringan suatu lahan. Tabel 3 menunjukkan bahwa UPT dengan nilai defisit tertinggi adalah UPT Bengawan Solo, sedangkan daerah yang sering mengalami kekeringan adalah daerah yang berada di DAS Bengawan Solo seperti Bojonegoro, Lamongan, dan Tuban.

Tabel 3: Defisit Air berdasarkan Unit Pelaksana Teknis Tahun $2008-2011\left(10^{6} \mathrm{~m}^{3}\right)$

\begin{tabular}{lcccc}
\hline \multicolumn{1}{c}{ Daerah } & $\mathbf{2 0 0 8}$ & $\mathbf{2 0 0 9}$ & $\mathbf{2 0 1 0}$ & $\mathbf{2 0 1 1}$ \\
\hline UPT Bengawan Solo & $-5.760,31$ & $-6.574,27$ & $-4.258,27$ & $-3.918,01$ \\
\hline UPT Madiun & $-4.350,15$ & $-6.339,02$ & $-3.122,60$ & $-4.172,72$ \\
\hline UPT Bango Gedangan & $-2.068,80$ & $-2.207,73$ & $-1.646,45$ & $-2.318,30$ \\
\hline UPT Puncu Selodono & $-3.669,69$ & $-2.404,32$ & $-3.136,85$ & $-3.028,12$ \\
\hline UPT Buntung Peketingan & $-1.909,02$ & $-2.130,95$ & $-1.556,83$ & $-1.743,71$ \\
\hline UPT Gembong Pekalen & $-1.114,87$ & $-1.378,79$ & $-1.685,73$ & $-1.143,35$ \\
\hline UPT Sampeyan Baru & $-676,88$ & $-2.002,20$ & $-1.256,66$ & $-868,93$ \\
\hline UPT Madura & $-1.469,90$ & $-1.903,15$ & $-1.354,79$ & $-1.610,33$ \\
\hline \multicolumn{1}{c}{ Total } & $\mathbf{- 2 1 . 0 1 9 , 6 3}$ & $\mathbf{- 2 4 . 9 4 0 , 4 3}$ & $\mathbf{- 1 8 . 0 1 8 , 1 8}$ & $\mathbf{- 1 8 . 8 0 3 , 4 9}$ \\
\hline
\end{tabular}

Sumber: Hasil Perhitungan

\section{Nilai Estimasi Air}

Nilai estimasi air masing-masing daerah didasarkan pada acuan harga penelitian Rodgers dan Petra (2005) dengan penyesuaian tingkat deflator PDRB subsektor tanaman pangan pada tahun yang diteliti. Berdasarkan hasil penyesuaian, maka estimasi harga air di Provinsi Jawa Timur seperti yang tercantum dalam tabel 4.

Tabel 4: Estimasi Harga Air Provinsi Jawa Timur Tahun 2000-2011 (Rupiah/m³)

\begin{tabular}{ccc}
\hline Tahun & Tingkat Harga & Harga \\
\hline 2000 & 100 & 298,66 \\
\hline 2001 & 112,90 & 337,19 \\
\hline 2002 & 123,53 & 368,92 \\
\hline 2003 & 130,52 & 389,81 \\
\hline 2004 & 137,00 & 409,15 \\
\hline 2005 & 156,87 & 468,51 \\
\hline 2006 & 173,97 & 519,59 \\
\hline 2007 & 186,04 & 555,64 \\
\hline 2008 & 206,35 & 616,29 \\
\hline 2009 & 215,93 & 644,90 \\
\hline 2010 & 230,92 & 689,67 \\
\hline 2011 & 248,13 & 741,07 \\
\hline
\end{tabular}

Sumber: Hasil Perhitungan 
Estimasi yang dilakukan untuk menentukan total nilai air masing-masing daerah di Provinsi Jawa Timur adalah dengan memasukkan indikator air biru, air hijau, dan air abu-abu ke dalam perhitungan. Nilai air hijau tetap dimasukkan ke dalam perhitungan meskipun air hijau dianggap given. Pemberian nilai pada air abu-abu dimaksudkan sebagai besarnya nilai yang digunakan untuk memulihkan kualitas air seperti sebelum penggunaan.

Turner dkk. (2004) menjelaskan bahwa perhitungan nilai air sangat penting sebagai bahan evaluasi suatu program atau kebijakan pemerintah. Mengacu pada pendapat tersebut, hasil estimasi perhitungan nilai air pada tabel 5 dapat dimasukkan dalam anggaran pemerintah seperti anggaran pemeliharaan bangunan irigasi sebagai investasi. Hal ini dianggap penting mengingat peran infrastruktur pendukung sektor pertanian masih rendah. Rendahnya peran infrastruktur pendukung dapat dilihat berdasarkan pengalokasian air terhadap kebutuhan irigasi dimana alat ukur volume atau debit air hanya tersedia di bangunan teknis, sedangkan bangunan setengah teknis, dan sederhana belum tersedia.

Tabel 5: Total Nilai Air Jawa Timur Tahun 2008-2011 (Miliar Rupiah)

\begin{tabular}{cl}
\hline Tahun & Harga Air \\
\hline 2008 & $22.522,35$ \\
\hline 2009 & $25.798,67$ \\
\hline 2010 & $22.815,60$ \\
\hline 2011 & $25.212,16$ \\
\hline Sumber: Hasil Perhitungan
\end{tabular}

Berdasarkan hasil pehitungan mengenai estimasi nilai air, dapat dilihat bahwa sumber daya air merupakan barang yang sebenarnya memiliki nilai yang cukup tinggi dibandingkan dengan input sektor pertanian tanaman padi lainnya. Berdasarkan tabel 6, nilai air untuk biaya usaha tani tanaman padi sawah berada pada peringkat tertinggi ketiga dengan kontribusi $16,07 \%$ setelah lahan $(36,98 \%)$ dan jasa $(21,66 \%)$. Tingginya nilai air dalam proses produksi tanaman padi mencerminkan betapa pentingnya peran air selama proses produksi, namun hal ini masih belum disadari oleh mayoritas masyarakat indonesia dikarenakan beberapa faktor, diantaranya yaitu air masih dianggap barang umum dan tidak adanya pasar yang mampu memberikan nilai terhadap penggunaan air (Fauzi, 2006).

Tabel 6: Biaya Usaha Tani Padi Sawah di Jawa Timur Menurut Jenis Pengeluaran Tahun 2008

\begin{tabular}{|c|c|c|}
\hline Rincian & Nilai (Ribu Rupiah) & Kontribusi (\%) \\
\hline Bibit/Benih & 235,99 & 0,84 \\
\hline Pupuk & $1.080,79$ & 3,86 \\
\hline Pestisida & 64,72 & 0,23 \\
\hline Pekerja & $2.831,64$ & 10,11 \\
\hline Lahan & $10.359,00$ & 36,98 \\
\hline Alat/Sarana Usaha & $2.106,00$ & 7,52 \\
\hline Jasa & $6.068,00$ & 21,66 \\
\hline $\begin{array}{l}\text { Lainnya (bunga, kredit, iuran, iri- } \\
\text { gasi, PBB lahan sawah, dll.) }\end{array}$ & 763,00 & 2,72 \\
\hline Air & $4.500,06$ & 16,07 \\
\hline Total & $28.009,20$ & 100 \\
\hline
\end{tabular}

Sumber: Departemen Pertanian (2008), diolah 


\section{Simpulan}

Berdasarkan hasil estimasi, dapat diambil beberapa kesimpulan, antara lain rata-rata nilai water footprint Jawa Timur tahun $2008-2011$ adalah $3.556 \mathrm{~m}^{3} /$ ton. Nilai water footprint dipengaruhi oleh perubahan iklim (tingkat evapotranspirasi dan curah hujan), penggunaan kuantitas pupuk, dan produktivitas lahan. WF perkapita tertinggi dari tahun $2008-2011$ secara berurutan berada di Kota Probolinggo (791,23 $\mathrm{m}^{3} /$ kapita), Kota Batu (861,89 $\mathrm{m}^{3} /$ kapita), Kota Pasuruan $\left(669,2 \mathrm{~m}^{3} /\right.$ kapita), dan Kota Blitar $\left(776,21 \mathrm{~m}^{3} /\right.$ kapita). Selanjutnya, rata-rata kebutuhan air Jawa Timur tahun $2008-2011$ adalah sebesar 35.913.244.065 m³. Nilai kebutuhan air yang lebih tinggi dibandingkan dengan alokasi air untuk tanaman padi disebabkan oleh acuan untuk alokasi air yang ditetapkan oleh pemerintah hanya sebesar $15.217 .810 .000 \mathrm{~m}^{3}$. Terakhir, estimasi nilai air di Provinsi Jawa Timur pada tahun 2008 hingga 2011 secara berurutan adalah Rp 616,29; Rp 644,9; Rp 689,67; dan Rp 741,07 per $\mathrm{m}^{3}$. Jika dimasukkan ke dalam struktur ongkos usaha tani padi di Jawa Timur, harga air berada di peringkat ketiga setelah lahan dan jasa, yaitu sebesar Rp 4,5 juta per hektar untuk satu kali musim tanam.

Berdasarkan kesimpulan di atas, beberapa saran terkait implikasi kebijakan yang dapat diajukan antara lain Dinas Pertanian, Dinas Pekerjaan Umum Pengairan, dan Badan Meteorologi, Klimatologi, dan Geofisika perlu melakukan koordinasi dalam menentukan alokasi air irigasi, khususnya air untuk tanaman padi, serta kejelasan informasi dari instansi terkait kepada para petani padi mengenai perkiraan datangnya musim hujan dan musim kemarau. Hal ini diperlukan karena kondisi riil untuk kebutuhan air irigasi lebih besar dua kali lipat dibandingkan dengan alokasi irigasi. Selanjutnya, pemerintah perlu memberikan dukungan infrastruktur untuk sektor pertanian, khususnya untuk bangunan irigasi setengah teknis dan sederhana pada musim kemarau. Hal tersebut dimaksudkan untuk menjaga stabilitas debit air pada saat musim kemarau. Pemerintah daerah diharapkan mengikutsertakan estimasi harga air kedalam anggaran daerah untuk pembangunan/perbaikan jaringan irigasi. Jumlah penggunaan air dapat dikurangi dengan dua cara, yaitu beralih ke tanaman padi gogo atau mengurangi produksi padi pada daerah yang memiliki tingkat produktivitas rendah. Cara pertama dapat dilakukan dengan meningkatkan produktivitas padi gogo/lahan kering/ladang, dimana padi ladang lebih sedikit membutuhkan air seperti yang telah disarankan oleh Pujiharti dkk. (2008). Cara kedua dilakukan dengan menanam tanaman pangan selain padi. Cara tersebut telah dibahas oleh Hoekstra dan Chapagain (2006) dalam penelitiannya mengenai penggunaan air sebagai fungsi dari pola konsumsi masyarakat.

Penelitian selanjutnya hendaknya menggunakan semua jenis tanaman pangan dan tidak hanya berfokus pada tanaman padi. Penelitian dengan mengikut sertakan semua jenis tanaman pangan diharapkan dapat memberikan informasi terkait potensi masing-masing daerah tersebut dalam memproduksi jenis tanaman pangan yang memiliki produktivitas tinggi dan meningkatkan produktivitas sumber daya air. Selain itu, data yang digunakan pada penelitian selanjutnya hendaknya mengikutsertakan data ekspor-impor padi/beras dari masing-masing daerah, karena surplus produksi padi tiap daerah tidak selalu seluruhnya digunakan di luar daerah produksi dan begitu juga untuk impor padi. Dalam konteks konsumsi, data tersebut diperlukan karena pada kenyataannya daerah yang melakukan impor padi/beras tidak selalu mengalami defisit padi/beras.

\section{Daftar Pustaka}

Agudelo, J. I. (2001). The Economic Valuation of Water: Principles and Methods.

Allen, R. G., Pereira, L. S., Raes, D., \& Smith, M. (1998). Crop Evapotranspiration: Guidelines for Computing Crop Water Requirements. FAO. 
Aylward, B., Seely, H., Hartwell, R., \& Dengel, J. (2010). The Economic Value of Water for Agricultural, Domestic and Industrial Uses: A Global Compilation of Economic Studies and Market Prices.

BKP. (2012). Tingkat Konsumsi dan Pertumbuhan Penduduk Jawa Timur.

BPS. (2010). Penduduk Indonesia Menurut Provinsi dan Kabupaten/Kota. BPS.

BPS. (2011a). Indikator Pertanian 2010/2011. BPS.

BPS. (2011b). Luas Panen, Produksi, dan Produktivitas Padi menurut Provinsi.

BPS. (2012). Pendapatan Nasional Indonesia. BPS.

Bulsink, F., Hoekstra, A. Y., \& Booij, M. J. (2010). The Water Footprint of Indonesian Provinces Related to The Consumption of Crop Products. Hydrology and Earth System Sciences, 14, 119-128.

Deliarnov. (2007). Perkembangan Pemikiran Ekonomi. PT. Raja Grafindo Persada.

Dinas PU Pengairan. (2011). Neraca Air Kabupaten/Kota Jawa Timur.

Direktorat Pengairan dan Irigasi. (2006). Identifikasi Masalah Pengelolaan Sumber Daya Air di Pulau Jawa. Badan Perencanaan dan Pembangunan Nasional.

Ditjen SDA. (2011). Isu Strategis dan Permasalahan Sumber Daya Air. Kementerian Pekerjaan Umum.

Falkenmark, M. (2003). Freshwater as Shared Between Society and Ecosystems: from Divided Approaches to Integrated Challenges. The Royal Society, 358, 2037-2049.

FAO. (2002). Crops and Drops. FAO.

Fauzi, A. (2006). Ekonomi Sumber Daya Alam dan Lingkungan. Gramedia Pustaka Utama.

Field, B. C., \& Olewiler, N. D. (2002). Environmental Economics (2nd ed.). McGraw-Hill.

Haryanto, T., Hidayati, N. A., \& Djoewito, W. (2009). Ekonomi Pertanian. Airlangga University Press.

Hoekstra, A. Y., \& Chapagain, A. K. (2006). Water Footprints of Nations: Water Use by People as a Function of Their Consumption Pattern. Water Resour Manage, 35-48.

Hoekstra, A. Y., Chapagain, A. K., Aldaya, M. M., \& Mekonnen, M. M. (2011). The Water Footprint Assessment Manual: Setting The Global Standard. Earthscan.

IFPRI. (2011). Ekspor dan Impor Padi Indonesia. http://www.foodsecurityportal.org

Kuo, S.-F., Ho, S.-S., \& Liu, C.-W. (2006). Estimation Irrigation Water Requirements with Derived Crop Coefficients for Upland and Paddy Crops in Chianan Irrigation Association, Taiwan. Agricultural Water Management, 82(3), 433-451.

Navrud, S. (2009). Value Transfer Techniques and Expected Uncertainties. NEEDS.

Pujiharti, Y., Barus, J., \& Wijayanto, B. (2008). Teknologi Budidaya Padi. Badan Penelitian dan Pengembangan Pertanian.

RECOFTC. (2012). Kita, Hutan, dan Perubahan Iklim. RECOFTC.

Rockström, J., Barron, J., \& Fox, P. (2003). Water productivity in rain-fed agriculture: challenges and opportunities for smallholder farmers in drought-prone tropical agroecosystems. CAB International, 145-162.

Rodgers, C., \& Hellegers, P. J. G. J. (2005). Water Pricing and Valuation in Indonesia: Case Study of The Brantas River Basin. In EPT Discussion Paper 141. 
Turner, K., Georgiou, S., Clark, R., \& Brouwer, R. (2004). Economic Valuation of Water Resource in Agriculture. FAO.

Unsworth, R. E., \& Petersen, T. B. (1995). A Manual for Conducting Natural Resource Damage Assessment: The Role of Economics.

Young, R. A. (1996). Measuring Economic Benefits for Water Investments and Policies. World Bank. 